\title{
Terrestrial Mollusks of Attu, Aleutian Islands, Alaska
}

\author{
BARRY ROTH' and DAVID R. LINDBERG ${ }^{2}$
}

\begin{abstract}
Seven species of land mollusk ( 2 slugs, 5 snails) were collected on Attu in July 1979. Three are circumboreal species, two are amphi-arctic (Palearctic and Nearctic but not circumboreal), and two are Nearctic. Barring chance survival of mollusks in local refugia, the fauna was assembled overwater since deglaciation, perhaps within the last 10000 years. Mollusk faunas from Kamchatka to southeastern Alaska all have a Holarctic component. A Palearctic component present on Kamchatka and the Commander Islands is absent from the Aleutians, which have a Nearctic component that diminishes westward. This pattern is similar to that of other soil-dwelling invertebrate groups.
\end{abstract}

RÉSUMÉ: Sept espèces de mollusques terrestres ( 2 limaces et 5 escargots) furent prélevées sur l'île d'Attu en juillet 1979 . Trois sont des espèces circomboréales, deux amphi-arctiques (Paléarctiques et Néarctiques mais non circomboréales), et deux Néarctiques. Si l'on excepte la survivance de mollusques due au hasard dans des refuges locaux, cette faune s'est retrouvée de part et d'autre des eaux depuis la déglaciation, peut-être depuis les derniers 10000 ans. Les faunes de mollusques de la péninsule de Kamchatka jusqu'au sud-est de l'Alaska on toutes une composante Holarctique. Une composante Paléarctique présente sur le Kamchatka et les îles Commandeur ne se retrouve pas aux Aléoutiennes, où la composante Néarctique diminue vers l'ouest. Ce patron est similaire à celui de d'autres groupes d'invertébrés terrestres.

Traduit par Jean-Guy Brossard, Laboratoire d'Archéologie de l'Université du Québec à Montréal.

\section{INTRODUCTION}

Attu $\left(52^{\circ} 55^{\prime} \mathrm{N}, 172^{\circ} 55^{\prime} \mathrm{E}\right)$, westernmost island of the Aleutian chain, stands approximately $730 \mathrm{~km}$ from Kamchatka and $1600 \mathrm{~km}$ from the North American mainland. Attu and its nearest neighbors, Agattu, $40 \mathrm{~km}$ to the southeast, and the Semichis, $32 \mathrm{~km}$ east by southeast, make up the Near Island group of the Aleutian Islands. Attu is composed of volcanic, intrusive, and sedimentary rocks of probable late Mesozoic to Pleistocene age (Gates et al., 1971). The island is mountainous, with peaks rising $860 \mathrm{~m}$ and $750 \mathrm{~m}$ above sea level.

The Near Island group is in a region of complex oceanic circulation (McAlister and Favorite, 1977). The southern region of the Near Islands is influenced by the westwardflowing Alaskan Stream. Between Attu and the Comman- der Islands ( $330 \mathrm{~km}$ west by northwest), the Near Current, a continuation of the Alaskan Stream, flows northward and then eastward off the northern shore of Attu. Also near Attu, the Commander Current, a southeastern extension of the East Kamchatka Current, joins the Near Current. Thus Attu is influenced by currents from both east and west, and has been noted by McAlister and Favorite for its propensity to collect drift bottles released from all directions.

Although Hultén $(1960,1968)$ included Attu in his Floras of the Aleutian Islands and Alaska and remarked (1960:32, 40 ) on the presence of certain typically Asian plant associations there, no detailed studies of the vegetation of Attu have been published. The flora and plant communities on Amchitka Island, $365 \mathrm{~km}$ to the southeast, have been de-

TABLE 1. Terrestrial mollusks collected on Attu, Aleutian Islands, Alaska, by D.R. Lindberg, July 1979

\begin{tabular}{|c|c|c|}
\hline Species and number of specimens & Sta. 1 & Sta. 2 \\
\hline \multicolumn{3}{|l|}{ Family VERTIGINIDAE } \\
\hline Vertigo modesta (Say, 1824) (1) & $\mathbf{X}$ & \\
\hline \multicolumn{3}{|l|}{ Family ARIONIDAE } \\
\hline Prophysaon sp., cf. P. boreale Pilsbry, 1948 (1) & & $\mathrm{X}$ \\
\hline \multicolumn{3}{|l|}{ Family VITRINIDAE } \\
\hline Vitrina pellucida (Müller, 1774) (1) & $\mathbf{X}$ & \\
\hline \multicolumn{3}{|l|}{ Family ZONITIDAE } \\
\hline Pristiloma arcticum arcticum (Lehnert, 1884) (2) & $\mathrm{X}$ & \\
\hline \multicolumn{3}{|l|}{ Family EUCONULIDAE } \\
\hline Euconulus fulvus alaskensis (Pilsbry, 1899) (2) & $\mathrm{X}$ & \\
\hline \multicolumn{3}{|l|}{ Family LIMACIDAE } \\
\hline Deroceras laeve (Müller, 1774) (2) & $\mathbf{X}$ & \\
\hline \multicolumn{3}{|l|}{ Family DISCIDAE } \\
\hline Discus cronkhitei cronkhitei (Newcomb, 1865) (24) & $\mathrm{X}$ & \\
\hline
\end{tabular}

LOCALITIES

Sta. 1. ALASKA: Aleutian Islands, Attu Island, Pacific Ocean, Massacre Bay. Under downed telephone poles alongside road from abandoned U.S.C.G. LORAN station to Murder Point. D.R. Lindberg, 13 July 1979.

Sta. 2. ALASKA: Aleutian Islands, Attu Island, Pacific Ocean, Massacre Bay, Casco Cove. Along creek bank south of abandoned U.S.C.G. LORAN station. D.R. Lindberg, 14 July 1979. 
scribed in detail by Amundsen (1977); the three basic plant communities on Amchitka - beach, low tundra, and high tundra - are also evident on Attu. Like the rest of the Aleutian Islands, the vegetation of Attu is alpine in character, with a few scattered subalpine associations on the slopes of sheltered valleys (Hultén, 1960).

The climate of Attu is wet and stormy. The lowest monthly mean temperature is $-1.4^{\circ} \mathrm{C}$ in January, the highest monthly mean temperature $10.6^{\circ} \mathrm{C}$ in August. The mean annual temperature is $3.6^{\circ} \mathrm{C}$. Attu is typically shrouded in fog and clouds, and visibility is less than two miles about 20 per cent of the year. Cyclonic storms are frequent from autumn through spring. Mean annual precipitation is $110.6 \mathrm{~cm}$ and mean annual snowfall is $283.0 \mathrm{~cm}$. Wind velocity averages $29 \mathrm{~km} / \mathrm{hr}$. Snow remains on the ground throughout the year at higher elevations and several glaciers occur in the mountainous interior of the island (climatic data from Gates and others, 1971).

In July 1979, D.R.L. accompanied a U.S. National Fish and Wildlife Laboratory team to Attu to assist in the yearly monitoring of sea otter populations. During this visit, terrestrial mollusks were collected at two localities on the Pacific Ocean side of the island. Field observations were also made on the Bering Sea side near Chichagof Harbor. Five species of snail and two species of slug were found on the island (Table 1). Both sample localities were in the transition zone between beach and low tundra plant communities (Fig. 1).

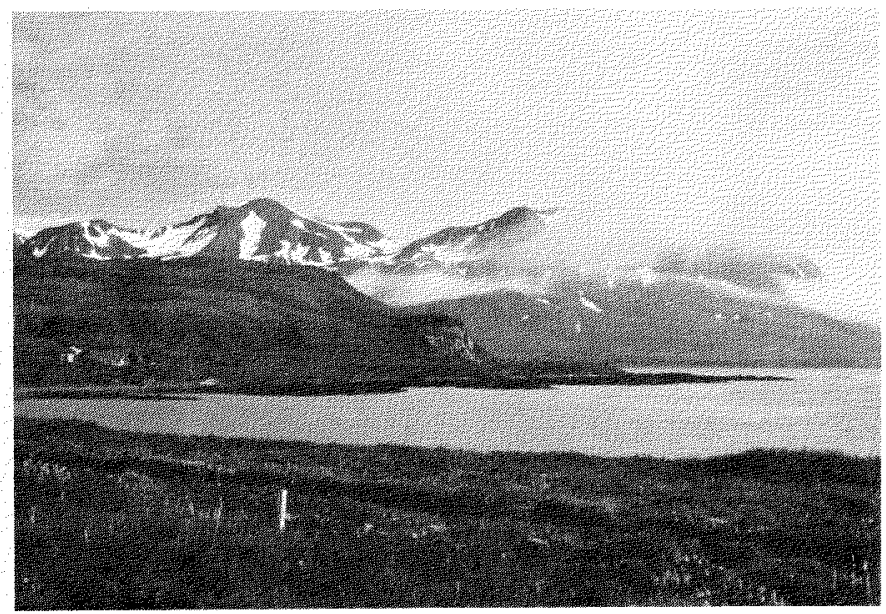

FIG. 1. Transition zone between beach and low tundra plant communities on marine terrace, Massacre Bay, Attu; generalized terrestrial mollusk habitat.

\section{FAUNA}

Specimens described herein are deposited in the mollusk collections of the California Academy of Sciences, San Francisco, California.

Vertigo modesta is circumboreal, becoming alpine in temperate latitutes (Pilsbry, 1948; Likharev and Rammel- 'meier, 1952; Bequaert and Miller, 1973). It is the common species of Vertigo in Alaska and is known as well from Chukotka, Kamchatka, and the Commander Islands. The single specimen has the tooth formula 1-1-2 common in northern populations.

The slug genus Prophysaon is indigenous to northwestern North America. Its range extends from southern Alas$\mathrm{ka}$ and the Aleutian Islands to central California, and inland to northern Idaho. Pilsbry (1948) listed eight species in two subgenera but acknowledged that species-level taxonomy of the genus was imperfectly known. The one specimen obtained is a dark, grayish-brown slug about $35 \mathrm{~mm}$ long in alcohol. The sole is buff, undivided; the mantle has two darker longitudinal bands along the sides. Behind the mantle a tan mid-dorsal stripe extends to the tail. About eight $\mathrm{mm}$ from the posterior end, the usual zone of abscission in tail-shedding prophysaons, the body is constricted and crossed by a $0.5 \mathrm{~mm}$-wide transverse raised seam. The pneumostome is located one-third the distance from the anterior edge of the mantle; its anterior mantle-flap bears two flat, finger-like projections. The reproductive anatomy seems typical of Prophysaon, with proportions similar to those in the dissection of $P$. boreale figured by Pilsbry (1948: Fig. 376B), except that the bulbous enlargement of the upper part of the vagina is absent. The muscular body of the epiphallus is curved, almost cashew-shaped, and half again as long as the penis. The hermaphrodite duct, convoluted where it emerges from the albumen gland, is longer, and the ovotestis somewhat larger, than any heretofore illustrated for the genus.

The present record is a westward range extension for the genus some $1300 \mathrm{~km}$ from Unalaska Island $(P$. andersoni [Cooper, 1872], reported by Hanna, 1925; Eyerdam, 1933; and Scheffer in Murie, 1959). If the vaginal configuration and other details prove to be more than just individual aberrations, they would imply independent species status for the Attu population. Samples from Unalas$\mathrm{ka}$ and elsewhere in southern Alaska should also be examined in this context. Prophysaon also occurs in the vicinities of Lituya Bay (Roth, unpublished), Taiya River (Pilsbry, 1948; P. boreale), and Copper and Martin Rivers (Tuthill and Johnson, $1969 ; P$. cf. $P$. andersoni), southeast Alaska.

Vitrina is represented by a single juvenile specimen with shell $2.5 \mathrm{~mm}$ in diameter. The protoconch consists of 1.25 whorls, as in V. pellucida (Müller, 1774) (Forcart, 1955) and is microscopically pitted in spiral rows. Early authors treated west American, Alaskan, and most Bering Sea island specimens as one species, V. alaskana Dall, 1905, and Siberia-Kamchatka-Commander Islands specimens as another, V. pellucida. Dissections by W. B. Miller (Bequaert and Miller, 1973) of Arizona V. "alaskana" showed that the reproductive anatomy is that of the Eurasian $V$. pellucida. Bequaert and Miller retained the name $V$. pellucida alaskana as a "convenience" designation for west 
American $V$. pellucida but cited no morphologic characters to differentiate the subspecies. $V$. pellucida is Holarctic, montane in the southern part of its range (Pilsbry, 1946; Likharev and Rammel'meier, 1952). It is said to be the most common land snail on most of the islands of the Bering Sea (Dall, 1905, as V. alaskana).

Pristiloma arcticum arcticum ranges in the western Nearctic from Point Barrow, Alaska, to Washington State (a weakly differentiated subspecies, $P$. a. crateris Pilsbry, 1946, is reported from near Crater Lake, southern Oregon); southern localities are near timber line. Likharev (1963) recorded $P$. arcticum in Kamchatka, Hokkaido, and the Kuril Islands (with $P$. japonica Pilsbry and Hirase, 1903 , in synonymy). It has not been recorded as far north in the Palearctic as in the Nearctic realm. The Attu record is about midway between the two other nearest records: southern Kamchatka (Likharev, 1963) and Unalaska (Dall, 1905; Pilsbry, 1946).

The two specimens of Euconulus fulvus have 4.5 whorls and a subangular periphery - characters of the subspecies $E$. f. alaskenis (Pilsbry, 1899), which ranges from the Norton Sound coast of Alaska (Dall, 1905; Pilsbry, 1946) to high elevations in Arizona. According to Pilsbry (1946), Dall's record from Petropavlovsk, Kamchatka, belongs to this subspecies. Eyerdam (1939) detected "practically no" difference between specimens from Kodiak Island and Kamchatka. The species in the broad sense is widespread in the Holarctic realm.

The Holarctic slug Deroceras laeve is the most widely distributed of these mollusks, with a remarkable thermal, latitudinal, and ecologic range. In the Americas it ranges from the Arctic Slope of Alaska (Hanna, 1956) to Central America; in boreal and temperate Eurasia, from Iceland, Scandinavia, and Siberia to Kamchatka (Bequaert and Miller, 1973). As a synanthropic introduction, it occurs in South Africa and Australia and on Pacific Islands. Deroceras laeve was the only mollusk observed on the Bering Sea side of Attu and the only one in the low tundra plant community in the interior of the island (Lindberg, field observation). Even $D$. laeve was absent from the high tundra plant community.

Discus cronkhitei cronkhitei is a widely ranging Nearctic form, occurring from the Kotzebue Sound area of Alaska (McCulloch et al., 1965) and the Aleutians to Chihuahua, Mexico, and east to the middle Atlantic states (Bequaert and Miller, 1973). Attu is a westward range extension from Unalaska. Dall (1905) and Bequaert and Miller (1973) remarked on the similarity of $D$. cronkhitei to the Palearctic Discus ruderatus (Studer, 1820) (reported from Kamchatka by Likharev, 1963), and it may be that one Holarctic species is involved.

\section{DISCUSSION}

In sum, the land mollusk fauna of Attu consists of three circumboreal species (Vertigo modesta, Vitrina pellucida, and Deroceras laeve), two that are both Palearctic and Nearctic but not circumboreal (Pristiloma arcticum arcticum, Euconulus fulvus alaskensis), and (assuming that Discus cronkhitei and $D$. ruderatus are separable) two Nearctic species (D. cronkhitei cronkhitei and Prophysaon sp.).

Except for its highest peaks and ridges, Attu was completely glaciated in Illinoian (Hopkins, 1967) and Wisconsinan time (Gates et al., 1971). The maximum extent of ice was evidently well beyond the present shorelines. Barring the chance survival of mollusks in local refugia, the present land mollusk fauna represents an aggregation assembled since retreat of the glaciers - perhaps within the last 10000 years. Distribution of the circumboreal forms offers no clue to their source areas; and as long as no distinctive genetic or phenotypic attributes are known to separate Nearctic from Palearctic populations, the question of where the founders of the Attu populations came from is an idle one. The same is true for the two amphiarctic taxa, Pristiloma a. arcticum and Euconulus f. alaskensis. Attu is merely within the ranges of these forms, and its colonization by them is the result of the same process of dispersal that maintains their ranges through time.

Platnick (1976) distinguished what he called "dispersion", a property of individuals, the process by which an organism is able to spread from its place of origin to another locality within its previously established range, as opposed to "dispersal", a property of taxa, the process by which a species or other group is able to spread from its previously established range to a different range. Dispersal, in this definition, occurs when a barrier is surmounted or when geological or ecological changes remove a previously existing barrier. The clearest evidence for dispersal, sympatry of two or more closely related species (Croizat et al., 1974), is not shown by any land mollusks in the area under consideration. The Attu populations of Prophysaon, and less certainly those of Discus cronkhitei, are western outposts of otherwise strictly Nearctic taxa. The glacial history of Attu essentially rules out a relictual origin. But without knowing whether the island has been continuously within their prospective (if not their realized) range, it is not possible to say whether Prophysaon and Discus cronkhitei have undergone dispersal sensu Platnick (1976) during the late Quaternary. It is not clear whether they have surmounted any barriers; and until the phylogenetic relationships of these mollusk groups have been more fully studied, the critical evidence is lacking.

Lindroth (1963) posed the question of how effective the Aleutian Islands are as a route for biotic dispersal, and concluded that for soil-dwelling invertebrates their role in Asian-American faunal interchange has been very small. Land mollusks also belong to the soil-dwelling category and show a similar pattern of distribution to the arthropod groups studied by Lindroth. In view of the impossibility of deciding from the ranges of Attu land mollusks whether dispersal (a change of prospective range) has taken place, 
the question might be better rephrased: where are the barriers to biotic dispersal, and, judging from the distribution of plant and animal groups, how effective are they?

Molluscan records for the Aleutian Islands are scarce, reflecting a paucity of interest. For comparison with Attu, faunal records from Kamchatka to southeastern Alaska have been assembled from the literature and the California Academy of Sciences collections, and their Palearctic, Holarctic, and Nearctic makeup analyzed (Fig. 2). These lists involve interpretation; other specialists might come

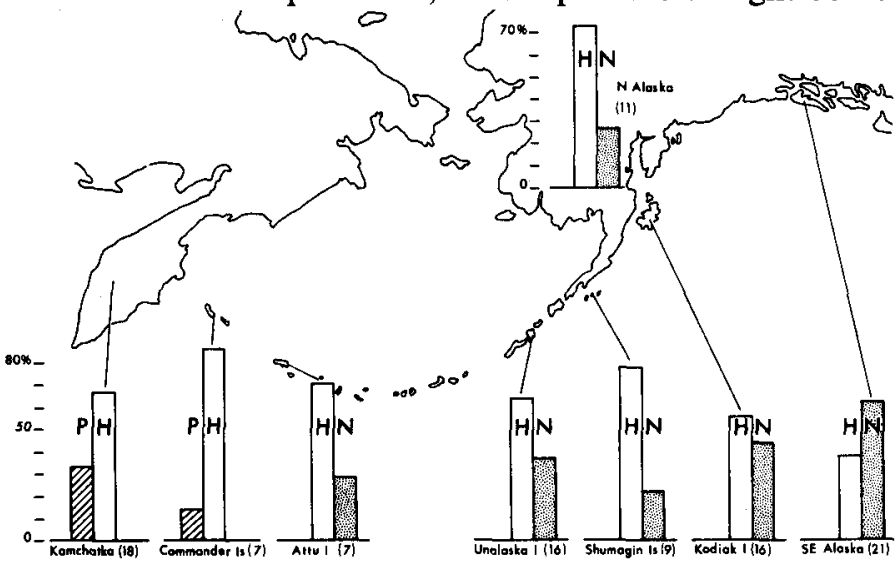

FIG. 2. Geographical analysis of terrestrial mollusk faunas of Kamchat$\mathrm{ka}$, the Commander and Aleutian Islands, islands near the Alaska Peninsula, southeast Alaska, and north of the Alaska Range. $\mathrm{P}=$ Palearctic, $\mathrm{H}$ $=$ Holarctic, $\mathbf{N}=$ Nearctic. Number of species in parentheses. (Compiled from Berry, 1937; Dall, 1905, 1917; Eyerdam, 1933, 1939, 1940, 1961; Hanna, 1925, 1956; Likharev, 1963; McCulloch et al., 1965; Roth, unpublished data; Tuthill, 1963; Tuthill and Johnson, 1969.)

up with slightly different assemblages. But the broad outlines of the picture would probably be the same in any case. All these faunas have a Holarctic component and, except for Kamchatka and the Commander Islands, a Nearctic component that diminishes westward. A similar pattern occurs among ground beetles (Carabidae) and other insect groups (Lindroth, 1963:122-123, Fig. 3), although both the latter groups contain a minor western (Palearctic) element that diminishes eastward. For vascular plants, a much larger Palearctic element is present, extending all the way to the Alaska Peninsula (Hultén, 1960; Lindroth, 1963: Fig. 1).

There is no overlap of Palearctic and Nearctic molluscan elements on the Aleutian Islands. The Palearctic molluscan element present on Kamchatka drops to zero on Attu. The beaches of Attu are littered with bamboo of apparent Asian origin and timber from unknown sources. The complex current systems affecting Attu have already been noted. Yet no mollusks otherwise restricted to Japan, the Kurils, or eastern Asia have been found there or on any other Aleutian island.

The strait between Attu and the Commander Islands seems to form a barrier for snails and slugs, as it apparently does, in part, for carabid beetles and other insects (Lindroth, 1963). Even the maximum Pleistocene eustatic lowering of sea level, $-130 \mathrm{~m}$ (Milliman and Emery,
1968), was insufficient to establish land connection between Attu and the eastern Aleutians. In the time since glacial retreat, therefore, mollusks from any source had to have reached Attu overwater; thus the absence of a land connection between Attu and the Commanders is not per $s e$ the barrier excluding Palearctic taxa. Field observation might help to establish whether wind patterns, ocean currents, or other factors are significant in North Pacific arc molluscan dispersal. Vagvolgyi (1975) reviewed the evidence for aerial dispersal among land snails of south Pacific islands.

If the Attu Prophysason proves to be distinct, with a limited, Aleutian range, like the beetle Nebria gregaria (Lindroth, 1963: Fig. 2), then the presence of a barrier to the east, between it and its sister-group in Prophysaon, would be indicated.

The mollusk fauna of southeastern Alaska (Fig. 2) includes a group of northeast Pacific rim species, chiefly of maritime and low-elevation habitat and mostly medium- to large-sized $(>10 \mathrm{~mm})$, that is absent north of the Alaska Range. Many of the species range southward in the humid coastal zone through British Columbia to Oregon and northern California. The group's limits are nearly those of the coastal coniferous forest of Alaska which Hultén (1960:44, Fig. 6) characterized as "of purely an American type". This maritime element diminishes northward and westward; the Attu Prophysaon is its most remote member.

Some authors (Dall, 1917; Eyerdam, 1933; Tuthill and Johnson, 1969) maintained that southeast Alaskan mollusks of the maritime group (e.g. Prophysaon, Vespericola columbiana [Lea, 1838], Haplotrema vancouverense [Lea, 1838]) were introduced by commerce. They cited the apparent association of these mollusks with zones of human habitation and the large amount of shipping between Alaskan and other Pacific Northwest ports. Hanna (1925), however, recorded Vespericola columbiana "many miles removed" from the spruce trees with which Dall (1917) thought they were brought to Unalaska; the snail was absent from spruce groves. The Alaskan ranges of these species are not markedly disjunct from their other occurrences. Association with human activity alone is not sufficient evidence of introduction, because ground-breaking for construction or agriculture can restore early successional plant communities that favor molluscan abundance and diversity (van der Laan, 1975). Perhaps the most important objection to the hypothesis of introduction, as long ago noted by Hanna (1925), is the large number of plant and animal groups which share a general northeast Pacific rim distribution.

During World War II, Attu was used as a military base, first by Japan and then by the United States. Large quantities of supplies and building materials were transported to the island, particularly during the American phase. Unfortunately, there are no mollusk collections made prior to 1940 to compare against the present collections. The two 
localities which yielded most of the species were on the Pacific side of the island in the transition zone between beach and low tundra plant communities, an area extensively developed by the American military. The mollusks collected and observed in this area were associated with construction debris.

Certainly, for the Holarctic forms at least, there is no need to invoke special circumstances for their occurrence on Attu; although construction activity could have created conditions, such as disturbed ground, favorable for their establishment or persistence. The geographic affinities of Attu Mollusca as a group are in accord with those of other biological groups believed to have established themselves naturally. The case for synanthropic introduction of Prophysaon would be further weakened by the finding of it on other Aleutian islands where there has been less human activity.

Prophysaon, alone of all the Attu land mollusks, is not known from the High Arctic. Its distribution in Alaska is southern and chiefly maritime and suggests that at one time the genus was confined to ice-free glacial refugia. For this reason, the Bering land bridge may have been unavailable to it, while for hardier High Arctic forms a relatively free faunal interchange was possible. Three other maritime species (Vespericola columbiana, Haplotrema vancouverense, and $H$. sportella [Gould, 1846]) extend no farther west than Unalaska (Hanna, 1925; Scheffer in Murie, 1959). These are all large $(>10 \mathrm{~mm})$ snails and would be expected to have dispersal characteristics like those of Prophysaon. If the apparent absence of Pristiloma arcticum arcticum from high arctic Asia is real, then the Aleutian arc, rather than the Bering land bridge, may at one time have served as a dispersal route for it. But in general the snails and slugs of Attu and the other Aleutian islands are most readily interpreted as part of the Nearctic molluscan fauna.

\section{ACKNOWLEDGEMENTS}

We are grateful to the National Fish and Wildlife Laboratory, Washington, D.C., and J.A. Estes, National Fish and Wildlife Laboratory, Center for Coastal Marine Studies, University of California, Santa Cruz, for D.R.L.'s opportunity to visit Attu. We thank David H. Kavanaugh and Dwight W. Taylor for alerting us to pertinent literature. The manuscript has benefitted from critical reading by Drs. Kavanaugh, Taylor, and Daphne F. Dunn.

\section{REFERENCES}

AMUNDSEN, C.C. 1977. Terrestrial plant ecology. In: Merritt, M.L. and Fuller, R.G., (eds.). The Environment of Amchitka Island, Alaska. Springfield, Virginia: Technical Information Center, U.S. Energy Research and Development Administration. 203-226.

BEQUAERT, J.C. and MILLER, W.B. 1973. The Mollusks of the Arid Southwest, with an Arizona Check List. Tucson, Arizona: University of Arizona Press.

BERRY, S.S. 1937. Land snails of Kadiak [sic]. The Nautilus 50(3): 87-88.

CROIZAT, L., NELSON, G. and ROSEN, D.E. 1974. Centers of origin and related concepts. Systematic Zoology 23(2): 265-287.
DALL, W.H. 1905. Land and fresh water mollusks of Alaska and adjoining regions. Harriman Alaska Series 13:1-171.

1917. Notes on boreal land and freshwater shells. The Nautilus 31(1): 12-13.

EYERDAM, W.J. 1933. A biological collecting excursion to the Aleutian Islands. The Nautilus 46(4): 124-128.

1939. Land snails collected at Uganik Bay, Kodiak Island. The Nautilus 53(2): 61-64.

1940. Further notes on land shells from Kodiak and nearby isiands. The Nautilus 53(4): 131-133.

1961. Mollusks and brachiopods from Afognak and Sitkalidak Islands, Kodiak group, Alaska. The Nautilus 74(3): 91-95.

FORCART, L. 1955. Die nordischen Arten der Gattung Vitrina. Archiv für Molluskenkunde 84(4/6): 155-166.

GATES, O., POWERS, H.A. and WILCOX, R.E. 1971. Geology of the Near Islands, Alaska. U.S. Geological Survey Bulletin 1028-U: 709822.

HANNA, G.D. 1925. Some land shells from the Aleutian Islands, Alaska. The Nautilus 38(4): 122-125.

1956. Land and freshwater mollusks of the Arctic slope, Alaska. The Nautilus 70(1): 4-10.

HOPKINS, D.M. 1967. The Cenozoic history of Beringia - a synthesis. In: Hopkins, D.M. (ed.). The Bering Land Bridge. Stanford, California: Stanford University Press. 451-484.

HULTÉN, E. 1960. Flora of the Aleutian Islands. 2nd edition. Weinheim, Germany: J. Cramer.

1968. Flora of Alaska and Neighboring Territories. Stanford, California: Stanford University Press.

LIKHAREV, I.M. 1963 [On the fauna of the terrestrial mollusks in the Kamchatkan region.] In: Portenko, L.A. (ed.). [The Fauna of the Kamchatkan Region.] Moscow, U.S.S.R.: Akademia Nauk. 65-81. [In Russian.]

and RAMMEL'MEIER, E.S. 1952. Terrestrial Mollusks of the Fauna of the U.S.S.R. [English translation, 1962, by Israel Program for Scientific Translation.]

LINDROTH, C.H. 1963. The Aleutian Islands as a route for dispersal across the North Pacific. In: Gressitt, J.L. (ed.). Pacific Basin Biogeography. Honolulu: Bishop Museum Press. 121-131.

McALISTER, W.B. and FAVORITE, F. 1977. Oceanography. In: Merritt, M.L. and Fuller, R.G. (eds.). The Environment of Amchitka Island, Alaska. Springfield, Virginia: Technical Information Center, U.S. Energy Research and Development Administration. 331-352.

McCULLOCH, D.S., TAYLOR, D.W. and RUBIN, M. 1965. Stratigraphy, non-marine mollusks, and radiometric dates from Quaternary deposits in the Kotzebue Sound area, western Alaska. Journal of Geology 73(3): 442-453.

MILLIMAN J.D. and EMERY, K.O. 1968. Sea levels during the past 35,000 years. Science 162: 1121-123.

MURIE, O.J. 1959. Fauna of the Aleutian Islands and Alaska Peninsula. U.S. Department of the Interior, Fish and Wildlife Service Bulletin $61.406 \mathrm{p}$.

PILSBRY, H.A. 1946. Land Mollusca of North America (north of Mexico). Academy of Natural Sciences of Philadelphia Monograph 3. 2(1): $1-520$.

1948. Land Mollusca of North America (north of Mexico), Academy of Natural Sciences of Philadelphia Monograph 3. 2(2): 521-1113.

PLATNICK, N.I. 1976. Concepts of dispersal in historical biogeography. Systematic Zoology 25(3): 294-295.

TUTHILL, S.J. 1963. Preliminary report of the molluscan fauna of the Martin River Glacier and associated area. The Veliger 6(2): 84-90. and JOHNSON, R.L. 1969. Nonmarine mollusks of the Katalla region, Alaska. The Nautilus 83(2): 44-52.

VAGVOLGYI, J. 1975. Body size, aerial dispersal, and origin of the Pacific land snail fauna. Systematic Zoology 24(4): 465-488.

van der LAAN, K.L. 1975. Feeding preferences in a population of the land snail Helminthoglypta arrosa (Binney) (Pulmonata: Helicidae). The Veliger 17(4): 354-359. 